\title{
Criminalization and self-control as "ruse of the conscious will" for Eduard von Hartmann
}

\author{
Criminalização e auto-controle como "artimanha da vontade consciente” para Eduard \\ von Hartmann
}

\author{
Ignace Haaz \\ Doutor em Letras pela Université de Genève (Genebra-Suiça) e pós-Doutor em Filosofia pela \\ Université de Fribourg/Universität Freiburg (Friburgo-Suiça). \\ E-mail : haazi@myopera.com
}

\begin{abstract}
Criminal law exists in order to punish people for their culpable misconducts, whenever there is a culpable wrong one should criminalize and punish. A distinctive moral voice: the criminal wrong that we don't find beyond is revealed and any normative ethical enquiry should point out, as a specific axiological and moral category related to such evil conducts. Why not suppose an unconscious genesis of it in the sensitive faculties, because there is a constitution of what man is, learned through history?

Eduard von Hartmann thinks that the normative role of self-control functions in different moral principles. This is valid also in criminal ethics. Thinking the process what begins to be morally relevant, as morally criminal is presented as "ruse of the conscious will": pre ethically, by specific psychological drives, and metaphysically by character formation.
\end{abstract}

Keywords: Pessimism, punishment, unconscious.

Resumo: Leis criminais existem para punir pessoas de acordo com suas infrações, quando há um culpado errado alguém deveria ser criminalizado e punido. Uma distintiva voz moral: o erro criminal que nós não encontramos além é revelado e qualquer investigação ética normativa o deveria mostrar, conforme uma específica categoria axiológica e moral relacionadas a tais más condutas. Por que não supor uma gênese inconsciente nas faculdades sensíveis, por que há uma constituição do que o homem é, ensinada através da história?

Edward von Hartmann pensa que o papel normativo das funções de autocontrole acontece através de diferentes princípios morais. Isto é válido também em crimes éticos. Pensando o processo que começa a ser moralmente relevante, o criminoso é moralmente apresentado como "artimanha da vontade consciente": pré eticamente, por específicos intintos psicológicos e, metafisicamente, pela formação do caráter.

Palavras-chave: Pessimismo, punição, inconsciente.

\section{Introduction}

Among Schopenhauerian philosophers as Philipp Mainländer, Julius Bahnsen and Eduard von Hartmann, we find various original critical reflections on the unconscious will and different evaluations of the role and meaning of suffering in human existence ${ }^{1}$. E. von Hartmann (1842-1906), in particular, has an underappreciated influence on the history of phenomenology, as part of normative ethics, in establishing the pertinence of a historical method for psychological observations. His remarkably rich concern with the origins of the unconscious mental life received and is still scrutinized

${ }^{1}$ See MÜLLER-SEYFARTH, 1993 and 2008; see REGINSTER, 2006. 
by contemporary literature ${ }^{2}$. The author of the "Philosophy of the Unconscious" addresses the philosophical interrogation of the utility of history for life, showing how moral psychology should be seen as combining evolutionism with axiology or eudemonism ${ }^{3}$. We find in von Hartmann's Phänomenologie (1879), and later in: „Die Axiologie und ihre Gliederung“ (1890) and in: “Ethik und Eudämonismus" (1898), the central idea that the capacities for suffering and sympathy have to be interpreted on the historical line of the genesis of the notion of the unconscious, and should be assessed according two criteria. It doesn't follow from an antinomy between the moral sentiments, as the point of view of the ethics of prudence (Glückseligkeit), and ethical life (Sittlichkeit) that this antinomy has the dissolution of eudemonistic axiology for implication. A foundation of the morals in eudemonistic ethics on the basis of pessimism and the lack of ethical ideal as an absolute personality don't suggest a wrong foundation of happiness, as an ethical claim on its nature we believe, and we shall see how von Hartmann structures on different levels his principles of moral sentiments, and other teleological guidelines ${ }^{4}$. It is important to notice that the polarity of the will and the reason is as essential to von Hartmann's moral philosophy, as the preconceived aim of a negative evaluation of existence. While this later thesis affirms that the presence of evil in the universe takes us to the very heart of all the other problems of life, the former claims that we share (with some non-human animals) an important part of our participation in the actualization of the will, in an "ursprünglichen Naivität" expressed by our sympathy. We should notice that sympathy is a mixed feeling for von Hartmann, who adds critical observations to Schopenhauer's views on compassion, confronting this notion with the production of a

\footnotetext{
${ }^{2}$ See JENSEN, 2012; WOLF, 2006. The strong impact on the history of the notion of the unconscious, and the direct relation to Nietzsche, regarding normative ethics, is worth to mention, see: JENSEN, Anthony (2012): „Das Unbewusste durch die Historie enthüllt: der bejahende Einfluss Hartmanns auf Nietzsche“, in: Nietzsches Philosophie des Unbewussten, Ed. by Georg, Jutta/ Zittel, Claus, Berlin: Walter de Gruyter Verl., 157. We let open the question how far von Hartmann (and before him Schopenhauer) borrows some of his most important arguments to Schelling, reproducing them in a much more systematic manner, in the field of the philosophy of nature, metaphysics, psychology, religion, ethics or aesthetics. This is true, in particular, concerning the principle of an unconscious mental power of the transcendental Anschauung, in Schelling's first period, and is also relevant concerning the duplicity of the orientation of the will, from the second period, as hedonism and asceticism. See: E. von Hartmann (1900), Geschichte der Metaphysik, Zweiter Teil, Ausgewählte Werke Vol. 12, Leipzig: Hermann Haacke, 169, 171, 175. See also: Hühn, Lore (2006): Die Ethik Arthur Schopenhauers im Ausgang von Deutschen Idealismus (Fichte/Schelling), Würzburg: Ergon Verl., 11-20.

${ }^{3}$ The idea of negative eudemonism, of happiness attainable through negation and opposed to absolute eudemonism, is a doctrine which is showing pessimism with regard to the value of life, according to the norm of happiness. A fuller interpretation of this idea, applied on the practical issues of blame, as prevention and retribution, can be found, for example, in the first part of: HAAZ, Ignace (2012): La solidarité chez Hegel, von Hartmann, Tocqueville et Mill, Coll. Commentaires philosophiques, Paris: Éditions L'Harmattan, 7-212. I am grateful to Prof. A. Duff and A. von Hirsch for inviting me to discuss von Hartmann's views regarding criminalization at the Special Workshop on Criminalization, at the IVR World Congress in Frankfurt, the 16-18 August 2011.

${ }^{4}$ The normative relations between happiness and the problem of evil qua pessimism are the center of a lifelong enquiry. Dissertations in normative ethics include: HARTMANN, Eduard von (1879): Phänomenologie des sittlichen Bewusstseins: Prolegomena zu jeder künftigen Ethik, Berlin: C. Dunker Verlag; (1890): „Die Axiologie und ihre Gliederung“, Zur Geschichte und Begründung des Pessimismus, A.I, Leipzig: Hermann Haacke Verl., 1-17. See in particular here for the coherence of this approach: (1898): "Ethik und Eudämonismus" in : Ethische Studien, Siebente Aufsatz, Leipzig: Hermann Haacke, 160, 174.
} 
subtle illusion, by a suspect pleasure of "Grausamkeitswollust". From that pre-teleological view, we are linked to the domain of the ethics of the moral sentiments. Without introducing a collective teleological aim of history, we would have to admit the punctual and exceptional character of moral virtuosity, in certain individual asceticism and outstanding human realizations with Schopenhauer or Mainländer in a quasi-Buddhist attitude ${ }^{6}$. This world view can be the logical consequence of the following analysis, related to our specific conception of vitalism as cosmological, political or religious set of arguments. A way of understanding the Schopenhauerian unconscious will is to consider the will without the teleological aspects related to our perception of the world as a whole with Mainländer (1886). But we could say that we don't see how such a simplification with Mainländer can give a structured religious or ethical meaning to a philosophy of redemption, as the overcoming in a new start the suffering of punishment. Interpreting redemption as psychological desperation cannot directly explain a possible unity on the higher level of teleology. Let's present Mainländer's reduction of all pantheistic will as a whole, in the world, to a supra-individual, but blind and aimless willing: the will to live "Wille zum Leben", and see on this level various possible propositions. We could be focusing on a will to will, a second order desire, since it is a desire to desire not a desire for determinate objects (e. g. food, a pen, walking in a garden). On this line human life seems to "swing" "between pain and boredom"". This will to life has a plausible cosmological and not religious alternative with Nietzsche's will to power: if the will to live does not exist, only: "where there is life is there also will: not will to life but - thus I teach you - will to power" (Thus Spoke Zarathustra, II, 12). Interestingly, this will to power sees the wish to preserve oneself as "the symptom of a condition of distress", that's why Mainländer's Spinozist or Darwinist reduction of the will as a whole, to a kind of self-preservation of life, and his solution of the individual "will to die" (Wille zum Tode), should be seen as a limitation of the really fundamental instinct of life as the expansion of power with Nietzsche (see The Will to Power, 688). If not "the joy of the circle" itself as a goal, becoming as self-creation turns to self-destruction because as willing creatures we cannot help having determinate desires, and in consequence we cannot complain that we have nothing to desire. On the contrary, in certain situations, we want to do something but are frustrated and bored not to be in the position to do (for example in jail).

\footnotetext{
${ }^{5}$ See for more critical materials on this topic: WOLF, Jean-Claude (2006): Eduard von Hartmann. Ein Philosoph der Gründerzeit, Würzburg: Königshausen \& Neumann, 32-33.

${ }^{6}$ Mainländer keeps the Schopenhauerian unconscious will without the teleological aspects related to our perception of the world as a whole: "der Pantheismus des Herrn von Hartmann aber steht in unserer Zeit da, wie ein Kinderschuh in der Garderobe eines Mannes, d.h. in romantischer Weise“. MAINLÄNDER, Philipp (1886/2011): „Kritik der Hartmann'schen Philosophie des Unbewußten“, Philosophie der Erlösung, 2. Band, 532, 537-8.

${ }^{7}$ See WOLF 2006, 24-25; REGINSTER 2006, 122-5.
} 
By opposition to Schopenhauer Hartmann thinks that, if suffering and sympathy are as important as rationality, in determining what to treat as an end in itself, Schopenhauer's (negative) eudemonistic view can be interpreted in a way which does not banish all plurality of individuals, in a collective deliverance from evil. This self-overcoming is the manifestation of the unconscious, unfolding not only a functional channel of self-realization of the character ${ }^{8}$ but also the ethically altruistic interpretation of redemption as a collective gesture ${ }^{9}$. Both evolution and negative eudemonism are not supposed to be contradictory. Following together religious, cosmic and simply political vitalism, the streams of unconscious life is not as much seen as splitting in various lifestyles, but in contrast it is conceived as building the concrete whole of existence, a bridge in relation to each individual $1^{10}$. Since it is necessary for human beings to follow any kind of finality, one cannot live without an ideal. Therefore the teleological view of evolutionistic optimism and the eudemonistic pessimism forms a unity for von Hartmann, following Schelling's positive philosophy, and summing up criticism of Hegel and Schopenhauer. This harmony is not a fusion of the idea and the will, two different principles inadequate in isolation, but the presentation of the condition of the decision of the will, under external or under self-imposed laws. In fact, a descriptive and historical point of view found in von Hartmann's work should be considered as an excellent starting point to reflect not only on a possible Neokantian foundation of normative ethics in phenomenology in the footsteps of Schopenhauer, Hegel and Schelling. Our concern will be to see how any particular kind of morality, as for example the evil of punishment, can be interpreted on the collective basis of von Hartmann's axiology, or at least, how the unconscious drive involved in retribution should not be interpreted. We shall try to apply von Hartmann's radical contribution to ethics to the question of criminalization ${ }^{11}$. As realizing the moral grounds related to the experience of suffering, we shall explore a diachronic point of view, not only on the question of a just reward or retribution, but more essentially we shall enter the realm of ethical normativity as an immoralist in the qualified sense, namely putting in perspective as historical evaluation a variety of conceptions of (heteronomous) morality, without rejecting genuine morality. This collective view of all feelings in the realization of the moral of sentiments is opposed to a single homogenous principle, and describes emotions of which every one engenders a moral

\footnotetext{
${ }^{8}$ See DARNOI, 1967.

${ }^{9}$ For an introduction on Hartmann's absolute moral principle, see also the notion of an unconscious God as postulate of his social quietism and escapism, cf. WOLF, J.-C. (2012): "Der Unbewusste Gott nach Eduard von Hartmann", in: Nietzsches Philosophie des Unbewussten, Ed. by Georg, Jutta/ Zittel, Claus, 31 ff. On the moral and psychological ground of the character, see: Darnoi, Dennis N. Kenedy (1967): The unconscious and Eduard von Hartmann. A historico-critical monograph, The Hague: Martinus Nijhoff, 113.

${ }^{10}$ For an example of how the philosophy of the unconscious and vitalism can be considered as basis of Buddhism, see Takeda, Sumio (2012): "Vitalism and Kegon Buddhism”, New Nietzsche Studies, Vol. 8, No 3-4, 73.

${ }^{11}$ The metaphysical position of E. v. Hartmann in the history of metaphysics is related to Plotin, Spinoza, Kant, Schelling, Hegel and Schopenhauer, just to name the more famous.
} 
principle (e. g. self-feeling as principle, but also remorse, etc.) Most of the immoralistic egoistical self-determinations can be seen as eudemonistic outlooks (and some perhaps as morale aristocratique à la Nietzsche), or as the antiauthoritarian solipsism (à la Stirner), if they qualify as growing stages of a higher moral principle, as self-legislation of practical reason. On this line the carriers of the moral principle of reason should in fine incorporate the moral principles of truth, the aspects of freedom, equality, order and justice for von Hartmann, and should attain maturity in consciousness, as the fullest consummation of the synthesis of the unconscious, in the entire process of evolution. If a study in the field of normative ethics is concerned by the problem of evil, following von Hartmann it is worthy to ask how this question applies in criminal law ethics, in particular also because von Hartmann was informed by the works of legal philosophers as A. Lasson (1882) and J. Stahl (1830-1837). Following von Hartmann, the classical problem of evil converges with the confrontation with an extramoral or premoral period of human history, as we find for instance in the second evil of punishment, in particular when retribution, as normative method, could be interpreted as having the optimistic intention of eradicating a first evil ${ }^{12}$.

A critical objection to a historical reflection arises; we are concerned by a very practical and concrete issue in criminal ethics: does a State-sanctioned punishment involve a moral reproach of guilt, and a will of control of a first evil, and if it does, how far is it not contra productive as heteronomous stage? If we don't agree with the necessity of a heteronomous remorse based principle, on which basis could we justify punishment, according to a concept that views the object of criminalization based on a criterion of self-control, without having to fall in a moralizing intention, or having to deny the meaning of morals as such? We will define criminalization and punishment in a broader sense, according to the impact of normative history on human life, and interpret A. Duff's account of legal moralism, in a way to rehabilitate morality in the realm of criminal ethics, but cum grano sali: without denying to the immoralist the force of challenging ours conceptions of morality, and to focus directly on our impulse to respond to the evil by a second evil. By the mean of his postulate of a unconscious synthesis, we shall follow von Hartmann's transformation of the Cartesian ergo sum in its contrary, namely that the unconscious material of our perception is the starting point of our psychology of the mind, building our conception of the legality, and of individual self-determination and freedom. On our lecture of legal moralism, the unconscious grows, once admitted in the conscious awareness, as the dog, that Faust once had let enter, so that clear intentionality should give some place in the room.

\footnotetext{
${ }^{12}$ If it was the case, then punishing would imply the will of "exorcising" devils "by Beelzebub" as Wolf puts it. It would be a deformation of the ethical and moral normativity of punishment, for the sake of an ideology of punishment; and we find the same misuse in the just war doctrine. See WOLF, Jean-Claude (2011) "Krieg gegen Böse, der Fanatismus der Tugend", in: Das Böse, Berlin/Boston: Walter de Gruyter GmbH, 131.
} 
According to the dogmatic approach, a person accused of a crime should be taken seriously as a person and not seen as a sleepwalker or a small child. He is expected to show concern if he is the object of moral reproach, recognizing a primary function to conscious intentionality, according a prima facie identification of consciousness and being. Before discussing the idea if self-control is really decisive for understanding criminalization, let us first take an example of how looking at consciousness as unproductive in the absolute changes our philosophical thinking of normative ethics and criminalization. Let's look at the question whether the reproach of guilt should lead to remorse. If that were the case punishment could imply guilt, because assuming responsibility for a tort could lead to an expression of irritation towards one's self, because of a lack of control of a specific type of behaviour. We would make, on this line, the assumption that certain means for reconciling with society could be found in remorse, and in determining the extent of punishment. According to von Hartmann, although remorse has a role in developing criminal norms, it should be considered normatively inapplicable. Is that to be understood in a strong immoralistic way, as the affirmation that we should not only ignore the morality of remorse, as a kind of vis inertiae, but claim that morality, as such, is a bad thing that should be rejected as a negative faculty of repression?

Hartmann seems close to the opinion according to which a victim forms an element of the idea of tort, that he has suffered, and that the State can assess a degree of shared responsibility in behaviours, in the same way that any person reacts in dealing with a constraint. Our evaluation of remorse should not be read as a camouflage, where we are missing what is taking place when we merely read the words: "torts", "remorse" and "culpability". There is a substantial description of a criminal tort, on the basis of the opinion that there is a distinct qualitative experience between two or several wills in any conflict ${ }^{13}$. We shall try to find confirmation that Hartmann describes the authority to whom we are responsible for a tort, when a community-based legal censure is imposed through conflicting wills and not only a sanction of morals. In his study of retribution, Hartmann states that an object of criminalization can consist in showing how retribution is transferred to the entire political community, in accordance with responsibility shared by the entire community. But then, how can von Hartmann not reinforce the feeling that violence must be turned against the blamed brutes, through a kind of moral terrorism? We shall look at the notion of retribution from the point of view of penal norms inspired by Hartmann's philosophy of the unconscious, and several extracts of his treatise on ethics, which has drawn little attention.

\footnotetext{
${ }^{13}$ See HARTMANN, Eduard von (1869/1889): "Die Entstehung des Bewusstseins", Philosophie des Unbewussten (Part 2, chapter III.1, tenth revised edition in three parts), Leipzig: Verlag von Wilhelm Friedrich, 38; in the English transl. : Philosophy of the Unconscious (1893), by W. C. Coupland, vol. 2, London: Kegan Paul, Trench, Trübner, \& Co. Ltd, 88.
} 


\section{To feel responsible for something: the ethical sentiment, the point of view of the character and intellectual understanding of remorse}

Conflict resolution requires that an individual suspected of having committed a tort seeks to reconcile with the rest of society through expression of remorse, otherwise his reintegration is impossible. Hartmann believes, however, that independently from the question of its expression, the very experience of a "reinforcement of remorse" "should overall be rejected and be advisedly limited where appropriated elements of an autonomous ethics are available, whether as taste, moral sentiment or reason ${ }^{14}$ " on the basis of existing feelings of one's self can be comforted, in order to strengthen one's ethical life.

In order to describe specific disadvantages of remorse from the perspective of moral psychology, I shall first point an ambiguity in the notion of satisfaction based on the negative character of pleasure or happiness. Since satisfaction is not understood as securing the possession of the object of one's desire, but as the possession, it doesn't comes to us sui generis, but as deliverance form a pain, i.e. from a need for an object. Therefore there is no positive benefit to possessing this object beyond the elimination of the need for $i t^{15}$. Because feelings differ depending on the ethical quality of an action, but is related to the victory of a momentary dominant desire, experienced by a criminal, a pleasure or a triumph, in function of the will adopted, which could be compared to the feeling experienced by a charitable nun in saving a human life, remarks comically v. Hartmann. It is only after that desire has diminished that correct evaluation and correction of errors are possible, and that a reproachable attitude or a previously unknown context creates clear awareness. When an error has a favourable effect, the unexpected benefits are welcome, but when it has an unfavourable effect, there is irritation at the lack of attention and commitment towards the goal considered to be correct. Self-love plays a role as intellectual stimulant against the irritation of the error, but only rarely does it have the final word, "because over time impartial comprehension does not allow the telling of tales ${ }^{16 "}$. Whoever is thus involved would be in desperation because he is "unable to undo what he has done ${ }^{17}$ ". Neither consciousness of the person charged as guilty of an incorrect action nor remorse in the strict sense is, however, the only way for this duplication of the self to occur, as Schopenhauer remarked ${ }^{18}$.

14 HARTMANN, Eduard von (1879): "Das Prinzip des moralischen Nachgefühls", Phänomenologie des sittlichen Bewusstseins: Prolegomena zu jeder künftigen Ethik, Sektion 2, A.II.3, Berlin: C. Dunker Verlag, 194-195; (henceforth $P s B)$. This point of view is still to be compared from the viewpoints of Spinoza and de Montaigne.

${ }^{15}$ See SCHOPENHAUER, Arthur (1873/1977): Die Welt als Wille und Vorstellung, I, §58, Zürich: Diogenes Verlag, 399. See also: Reginster, Bernard (2006): The Affirmation of Life, Harvard, UP, 115.

16 "Das Prinzip des moralischen Nachgefühls", PsB, Section 2, A.II.3, 184.

${ }^{17}$ Ps $B, 184-185$.

${ }^{18}$ See SCHOPENHAUER, A. (1841/1995): On the Basis of Morality, §9. See also: KANT, E. (1797/1994): Metaphysics of Morals II, I.I, $\S 13$. 
Interestingly, Hartmann follows him in rejecting the thesis of a moral conscience, where we would be both accuser and judge and where we would thus be at a disadvantage before that tribunal, in a sort of "legal drama" in order to defend the argument according to which self-duplication is something that is not essential to the conscience. It would be best to identify "a conflict of contrasting motives ${ }^{19}$ ". Within the framework of contrasting motives, ethical remorse greatly resembles egoistical remorse or purely natural remorse. Egoistical remorse is described as pseudo-ethical intellectual thinking about what can raise one's individual happiness, after an omission, while natural remorse is relegated to the study of the character as a psychological factum. One might highlight, from a dogmatic point of view, that being guilt prone should be seen in a positive sense of having a great sense of responsibility for others, by being aware of our own past mistakes, without meaning that persons are perpetually feeling guilty for things that they haven't done. On this line, shame would be linked to low self-esteem, a negative judgement on the whole self, whereas guilt is a negative evaluation of a particular action, which appears positive on this contrasting ground with the notion of shame or self-esteem as a totality. According to Hartmann, in seeking to stress the interest of remorse, its defenders have a tendency to attribute an ethical element to non-ethical characteristics, thus creating obstacles to ethics ${ }^{20}$. All remorse reposes on a desire contrary to experience of possessing the capacity to undo what has been done and on the pain caused by the impossibility of that happening. By raising remorse to a condition sine qua non, or by recognizing it as only an important instrumental value in order to live an ethical life, we lose access to an ethical life, or see the hope of its realisation decrease, as soon as reason registers this characteristic. (Pseudo-) ethical remorse "depresses the felling of one's self", decreases ethical force, by weakening confidence in that same feeling, and "leads to ethical impotence and to helplessness by sustained repetition along an ascending line ${ }^{21}$ ". The benefit of remorse is not to be excluded in the case of an incarcerated criminal, suggesting that all ethical consideration of remorse should not be suppressed, but even in that case benefits would be difficult to measure ${ }^{22}$. Von Hartmann is demonstrating the socio-moral function of moral principles based on self-esteem, while deflating the legal moralists' pretensions to having grasped the real way human being engage with remorse in generalizing the experience of punishment, he concludes:

Most of us, who are today neither convicts nor brutal savages but have had for the most part the chance to enter life as adults with an aware and active ethical

\footnotetext{
${ }^{19}$ On the Basis of Morality, $\S 9$.

20 "Das Prinzip des moralischen Nachgefühls", PsB, Section 2, A.II.3, p. 194.

21 "Das Prinzip des moralischen Nachgefühls", PsB, Section 2, A.II.3, p. 194. See also my own analysis of shame and blame, cf. Haaz, La solidarité, 21-31, 39, 44, 47.

${ }^{22}$ See "Das Prinzip des moralischen Nachgefühls", PsB, Section 2, A.II.3, p. 195.
} 
conscience, we want to be educated through other means and have other means for gaining knowledge and be stimulated for an ethical life [than remorse] ${ }^{23}$.

If the ethical conviction of being one's own end, the principle of autonomy is an important conviction, then remorse could still be a means of forming human qualities. The positive ethical sentiment of one's self, in one's own dignity, should correspond to a full, loyal and benevolent humanity, but Hartmann raises the question ironically ${ }^{24}$ :

What could go beyond the proud conscience of the self of my ethical conviction, when that ethical conviction is a purpose in itself and the very purpose of my life? Ethical taste is already protesting against that, in other words, ethical judgement not yet conscious of its basis. Making that the essence of ethical conviction, which can be cultivated only as inner life, inevitably carries a type of moral egoism, in other words the tendency to sufficiency at any cost ${ }^{25}$.

A stronger way to understand respect and human dignity would be to develop the difference between a concentration and an expansion of feelings, but not by keeping the sole teleological point of view of the first ${ }^{26}$. This line of material ethical reasoning mirrors the way of thought which distances Hartmann (and Nietzsche) from Darwin and Hegel. To follow the historical function of moral psychology, and to envision the incorporation of commitment of individual will in the community, favouring a pessimistic eudemonia, should not stray from the diversity of men against teleological hegemony, restoring the innocence of becoming in the disengagement with teleology ${ }^{27}$. Let us now see this evaluation of self-control, as an important instrument of ethical life in community where the teleological significance of life is as important as the innocent play of the child or the Buddhist blissful ignorance of the evil ${ }^{28}$. This proviso is central when we come to the question whether self-control should be seen as the corner stone in the normativity of criminalization, since the immersion in the experience of the subjectivity as a whole should incorporate something chaotic, Nietzsche would say the infinitude of the ocean ${ }^{29}$. The solitary laughing and swinging innocent play of the thinking faculty for Nietzsche keeps distance from the world, and as will to power, chooses the way the will can come

${ }^{23}$ PsB, Section 2, A.II.3, p. 196.

${ }^{24}$ I take inspiration from Stoecker's systematic thoughts on dignity. See STOECKER, R. (Ed.): Menschenwürde Annäherung an einen Begriff, Vienna, 2003.

25 "Das Prinzip des moralischen Selbstgefühls", PsB, Section 2, A.II.2, p. 181.

${ }^{26}$ PsB, Section 2, A.II.2, p. 182.

27 See HARTMANN, Eduard von (1896/1900): "Sozialdemokratie und Anarchismus als Abspaltungen aus dem Liberalismus", Zur Zeitgeschichte: neue Tagesfragen, Leipzig: Hermann Haacke, 86-88 and 94-95.

${ }^{28}$ Baumann already formulated the thought that self-control should be seen as the proper aim of punishment. See Baumann, Johann Julius (1879): "Das Recht überwiegend von Seiten der Gemeinschaft betrachtet", Abriss der Rechtsphilosophie, Leipzig: Verlag von S. Hirzel, §59, pp. 433 and 434.

${ }^{29}$ Cf. NIETZSCHE, F. "Von alten und neuen Tafeln“, Zarathustra, III, 12, 255. Nietzsche, F. (1884/1999): Also sprach Zarathustra, Werke, Kritische Studienausgabe, Hrsg. G. Colli und M. Montinari, Berlin: W. de Gruyter, 4, III, 12 , 255. 
back to the world, before restarting this circle. It reminds a possible interpretation of the Schopenhauerian will to live, and because it supposes a circle, and the return of the same content, as explained by von Hartmann $\left(1898^{30}\right)$, it can be considered as an antidote against pessimism, or on the contrary, as a superficial first impression "oberflächlichen Vordergrunds Ansicht", it is the point of view of the blind and irrational will, instead of being the acceptation of the voice of reason. It is hard to say, it depends on our understanding of the problem of evil and pessimism.

\section{Answering for a crime: observations of an ethical evolutionist in countering the argument of self-control of legal moralism}

From a dogmatic point of view, for the category of restrictions based on morally incorrect behaviour regulated by law, it seems that there are few obstacles to application of a sort of genealogy of blame as stated by Spinoza, and we may extend the materiality of the tort to legal regulations ${ }^{31}$. To be responsible, in other words to be in a position to answer, is based on a relational description of self-control described by legal moralism, that we can compare with Hartmann's observations based on metaphysical monism and ethical evolutionism. The penal ethics of Duff's contemporary legal moralism allows us to focus on the conditions of criminal responsibility, namely on the object of the criminalization strictly speaking, from the point of view of a legal moralist. Should we simply keep that sort of thought experiment, having an exclusive use of teleological thinking, or should we say that life is and will always be a problem, and that we cannot understand what is about ourselves which contains our high (but morally and legally obedient) possibilities. Hartmann describes conditions that would be impossible to categorize as rational self-control, because they are linked to coherent processes of behaviour but do not answer to the principle of reality, in a teleological agenda, usurping the spontaneity of our instincts. He stresses that certain types of self-control are anarchical, to the extent that an idée fixe and/or an obsession determine centrifugal egoistical tendencies, but starting from an individual purpose of lower order, without the misguided aims of forcing the ends we want. Thus, to trick someone, to pretend or to hide one's true intentions require an obvious self-control. A rational criterion of self-control implies taking into account part of a set of norms of taste and moral sentiments, and not only a subspecies of the principles of ethical freedom in the species of rational moral principles, because subjective ethics is a comprehensive totality for Hartmann ${ }^{32}$. If an

\footnotetext{
${ }^{30}$ HARTMANN, Eduard von (1898): „Nietzsches „Neue Moral“““, in: Ethische Studien, II, 57-59.

${ }^{31}$ SPINOZA, Baruch (1677/1985): Ethics, III, P.XXIX, scholie.

32 HARTMANN, Eduard von (1869/1889): Preface to the second edition, No. 53 (p. 134), "Charakter und Wille", Philosophie des Unbewussten, Tenth edition, Third part, First volume, V, p. 142.
} 
intellectual dimension is necessary in order to enlighten individual will, a large set of reasons that allow mobilization of will in a decision are presented by the German philosopher.

According to Duff, self-control could be an ideal candidate for a normative description that specifies the object of a criminal prohibition as opposed to reasons for punishment, which would not be limited to behaviour that would require censure within a community. It would even be possible to moralize legally behaviours for which there is no established moral tort, if we admit as evident that each person should maintain control over certain actions when confronted with a source dictating rules of good conduct. In contemporary theory, Duff stresses the component of intentionality of criminalization and blame in trying to include legal prohibitions created from artificial regulations incorporated into laws. In that way, non-conformity with a regulation should be criminalized, with the condition that there are moral torts of a type that merits public censure and punishment ${ }^{33}$. It can occur that a legal regulation exists in the form of an administrative sanction with a penalty and not with a penal sanction, a situation that allows criminalization of a behaviour sanctioned by an administrative instance, which is already subject to a legal sanction before being criminalized. Identification of an intentional object of penal responsibility can occur without a plan for quantification of punishment. In contrast, to ask how long a punishment should be, for example until expiation of a wrong or reinsertion in a human community, assumes an established difference between conditions of responsibility, and the object for which a person is held criminally responsible.

In contrast to a rather dogmatic legal moralism, Hartmann argues for levels of balance after adoption of ethical principles, and like Hume he tends to see the basis for responsibility in character rather than in rational choice ${ }^{34}$. This orientation does not seem to justify stressing the object of criminalization. It gives instead a temporizing and a quantity through presentation of the purpose of rehabilitating certain criminals in a legal order, by guaranteeing their best possible status. Contrary to Hume, however, who sees punishment not so much as a question of criminal responsibility but rather than of utility, in other words as rules linked to a given public end, Hartmann's ethics give a relational touch to what he calls "true principles of ethical life". That includes, moral principles of duty, retribution, legality and justice, thus placing the question of responsibility towards others in the foreground $^{35}$. This affirmation requires, however, important nuances concerning the way used to define criteria for someone assuming responsibility for something. In a way that seems rather analogous to the unconscious character of Hartmann's historical process, Duff's legal moralism supposes that

\footnotetext{
${ }^{33}$ See DUFF, R. Antony (2007): Answering for Crime, Portland, Oregon: Hart Publishing, pp. 82 and 91. See also Moore, Michael (1997): Placing Blame, Oxford: Clarendon Press, p. 662.

${ }^{34}$ See: HAAZ, Ignace (2009): „L'invention des conventions de justice chez Hume“, in: L'invention philosophique humienne, Philippe Saltel (dir.), Grenoble : Université Pierre Mendès France, 233, 243, 268-272.

${ }^{35}$ See „Das Moralprinzipien des Gegengefühls“, „Das Moralprinzipien des Pflichtgefühls“, „Das Moralprinzipien der Rechtlichkeit und Gerechtigkeit“, PsB, Section 2, A.II.4, 10, and A.III.8.
} 
epistemic conditions, in other words those about which a person should be aware, concern first of all not one's responsibility but rather rules of liability. Thus, rules can be recognized as non-applicable under certain conditions of justification and excuse. On the other hand, a responsibility remains established at various levels in a society among its members, because each member can be held to conditions of self-control ${ }^{36}$. This condition of control of behaviour is an assumed reciprocal norm, in an agreement shared among citizens, in order to ensure pacific coexistence in society. However, control of others raises questions, for example when certain behaviour is discovered only through police investigation, and which would have gone unnoticed without its action. Which degree of reciprocal responsibility should each member of a community take on, and expect from others, knowing that limits must be recognizable, when faced with an unjustifiable intrusion into everyone's private life? A condition of rather broad self-control takes on a form of normative responsibility to the same extent, because although in fact I can hold someone responsible prima facie for an action, which I feel that person should have been able to do, I cannot demand that a person be recognized responsible for conditions of an action, that I admit he could not control. One specific aspect of a sociable human being is to be able to enforce the requirement of controlling an action, when confronted with a negative freedom; in other words not limiting another person unjustifiably. In order to limit the normative nature and not the logical nature of this control, this criterion requires that control of behaviour be made under reasonable terms. As a consequence, a strong presumption exists in favour of a person with self-control, through a framework of reasonable limits, who ends up refusing to take into account previous intervals of time in self-determination, which weakens that specific control. We can exercise our control over various movements of the body, and we are supposed to master our thoughts, our emotions and our character, but there is rather little sense in evoking a criminal responsibility given a very broad range of states of mind, although all these dimensions of the human psyche contribute to rational self-control. Two types of observations are proposed by Hartmann's evolutionist ethics, in favour of a rather broad approach of criminal responsibility, where self-control is not seen as an unconscious historical process, but grounded on a rather thick epistemic level ${ }^{37}$.

Self-control presented by legal moralism as a condition of responsibility supposes that the striving for goals and aims are essential to adult life. Once the urgency of the imperative to experience pointless meanings, discontinuous non teleological experiences, along with growing up in a series of continuous transformation, we come to the evidence that there is no moral principle of self-control. The requirement of control is only "a condition for a sound ethical life and conscious of itself", as

\footnotetext{
${ }^{36}$ See DUFF, Answering for Crime, p. 16.

${ }^{37}$ See DUFF, Answering for Crime, pp. 57, 60 and 62. 
Hartmann calls $i^{38}{ }^{38}$ Legal moralism adds a criterion of rationality in a rational normative situation, but it should be kept in mind that there are non-rational situations of self-control and the very norms of self-control could be questioned in terms of evolutionary psychology. The creative part of the organization of life eludes rational productive appropriation. Self-control is a condition for my ethical existence and is a stage of psychological development of my own understanding of myself, without constituting a full normative ethical principle. If I consider self-control, I immediately have to consider also the creative part of the self, in a blissful energy, a first movement, a sacred yes, supposing blindness between past and future goals, as would do the spontaneous play of the child.

For Hartmann, whenever an individual shows self-control, he overcomes the rest of his reasons for action in order to pursue a conscious goal consequently, whether rational, irrational, moral or immoral. In contrast to Duff, Hartmann defends a strong epistemic criterion, and so he mirrors the mute experience of unconscious immersion in life. When we view self-control purely negatively through conflicting motives, the content of an activity still has to possess a determinate value, which is independent of the fact that it involves specific motives, let's say for example because they would be difficult to achieve, and not as first order desire to control ${ }^{39}$. The difficulty is to isolate a rational criterion of shared agreement, on the basis of the mediating value of self-control, because self-control can exist without being strictly ethical, and also without rational formulation, or without a criterion taking into account others ${ }^{40}$. The mediating ethical value of self-control appears to the extent, that an important part of activities contrary to an ethical existence obey impulsions of the senses, which does not imply that self-control serves an immediate ethical goal or represents an ethical principle. There are states of mind where self-control is accompanied by irresponsibility or lower kind of responsibility and be considered outside the domain of ethical self-control. In cases of certain mental disorders, self-control can serve to execute an obsession, or be related to the monotony of a compulsive disposition. Hartmann shows that "the person who thinks he is a king takes care to protect his dignity, against any challenge that he is not the king. Likewise, whoever considers his own body to be fragile as crystal, timidly avoids any free movement". A neurotic can use his own self-control "to hide his state from his entourage". It is on the basis of this observation of ordinary psychology, that Hartmann demonstrates that there is indeed self-control that serves to inhibit episodes of fantasy, which otherwise would lead to action, and that part of ourselves determined by our self-control moderates representations, that arise quickly to form reasons to act.

\footnotetext{
${ }^{38}$ HARTMANN, Eduard von, "Die Selbstbeherrschung", PsB, Section 2, A.III.4.5, p. 424.

${ }^{39}$ The sole fact of mastering a resistance doesn't give a virtual moral constraint. Cf. REGINSTER, The Affirmation of Life, 181 .

${ }^{40}$ HARTMANN, Eduard von, "Die Selbstbeherrschung”, PsB, 425; see also: 426, 436.
} 
Distinct from these limits, there are also conscious non-ethical goals in an immoral sense (not amoral), which require great self-control. If it is crucial to have a talent for simulation, when we are a person with bad or even criminal intentions, it can be said that nothing is more indispensable, to the criminal dissimulation, than control of one's self. Reproaching a criminal's lack of self-control tout court is unjustifiable. Hartmann, however, goes farther than a critique of basic comprehension of responsibility, which believes there is no need for a specific interlocutor in order to be required to answer for an action ${ }^{41}$. Without leaving aside the authority to which we would have to answer for an incorrect action, he compares normative self-control to the result of a psychological process that is determined by a will that stands out among a set of psychological drives assuming responsibility. It would be as wrong to ask a "locomotive engineer", compared with "the strength of a locomotive", which is one "thousand times stronger" than he is, to hold it back by the effort of his arms and shoulders, as to require self-control that the will be strong and sufficient enough, in order to carry out a positive action immediately, and to repress all affects and passions ${ }^{42}$. Since presenting appropriate "counter motives" suffices, to functions in relation to the unconscious drives of the weakness of will, like the arms of a locomotive engineer, when he moves a locomotive forward or in reverse, self-control appears as "a sort of ruse of the conscious will", in order "to direct the forces of nature, which are dormant in the spirit", towards his intentions ${ }^{43}$.

In contrast to the approach according to which rational agreement about self-control is rational to the extent that it manifests a high degree of our rationality, ethical productions of the spirit might well be highly rational and adjust to an immediate and intuitive thought, instead of a self-controlled reflection $^{44}$. As a pseudo principle, self-control can serve as an ethics of prudence and also lead to realization of the morality of a heteronomous authority. That is an insufficient condition for a practice conception of rules. From the legal point of view, the vehicle of self-control does throw an interesting light, but that is terrifying in many ways, because of the relationship between an accusation and the way in which a judge can hold an accused responsible for his incorrect behaviour ${ }^{45}$. While there are few ways to learn about the psychological process of a person charged, before he acts. In the absence of justification that would permit excusing the accused, a judge decides that the suspected moral responsibility prevails, on a normative legal level, in cases where it seems that there is no difference between lack of self-control, related to psychological negligence and a punishable act. As a result, ${ }^{41}$ See GARDNER, J. (2003): “The mark of responsibility”, Oxford Journal of Legal Studies, 23, cited in Duff, Answering for Crime, 25.

${ }^{42}$ HARTMANN, Eduard von, "Die Selbstverläugnung", $P s B, 436$.

${ }^{43}$ PsB, 436.

${ }^{44}$ We leave aside the problem of what is considered normal sanity in expressions such as "crazy (im Wahnsinnigen)", "our normal life goals (unsere normalen Lebensziele)", etc. See Hartmann, Eduard von, "Die Selbstbeherrschung", PsB, 422 and 424-427.

${ }^{45}$ See $P s B, 428$. 
beings responsible for their actions suppose a consciousness, developed to such a degree that it can understand the notions of moral and immoral. A judge makes individuals "responsible only for those actions which their consciousness was not prevented from measuring by its own standard ${ }^{46 "}$. This evolution may never arrive by teaching; "for the finest knowledge of ethics is dead knowledge if it does not act as motive on the will" and "whether it shall do so depends solely on the nature of the individual will". Conscious self-control does not cause a direct transformation of the unconscious synthesis of the character, which may be modified "by practice and habit", "through intentional or accidental partiality of the motives appearing before consciousness ${ }^{47}$ ".

The historical philosophic approach of German idealism, under the influence of Schelling's first system, leads to the idea of transcendental idealism and the principle of an unconscious Unity ${ }^{48}$. As a development of principles of ethical life, a substantial understanding of the notion of responsibility is based on an axiological priority for Hartmann, as a genealogical prefiguration of the relational awareness of human behaviour, through a responsible set of norms. Because a negative eudaemonist component is central, the set of norms of the responsibility is part of a historical process that could blurs the substantial element of the criterion ${ }^{49}$. Should we understand that within a historical process, the reciprocal agreement on the responsibility of each and every citizen does not make much sense, because there is only "a ghost" of equality of rights ${ }^{50}$ ? The avant-gardist and elitist social model of an association of egoists, as Stirner explored it, interprets in an social and ethical anarchist way all kinds of conventional or historical totalities, as "enemies" in a metaphorical sense, because the right of the personality and the sovereignty of the individuum, in Stirner's Neohegelian view is not only an alternative "culture de la Bohème", but primarily concerned by our self-education on the path to an utopic association of individuals. This point of view may be applied on concrete social problems, as for example the deconstruction of retaliation and the individual creation of new values by seeing beyond resentment's values ${ }^{51}$. The conditions which prevent individuals and societies from being "higher beings" are not that they are less unified in a context where they are held together by values, one may think, but that they are too structured by conventions or reactive forces that aim at

\footnotetext{
46 "Das Unbewusste in Charakter und Sittlichkeit", 231; transl. 266-267.

47 „Die Blutrache wäre bei uns unsittlich, bei Völkern von geringerer Kultur ist sie eine sittliche Institution“. ”Das Unbewusste in Charakter und Sittlichkeit", 231; transl. 265.

${ }^{48}$ See HARTMANN, Eduard von, (1869/1889): "Vorwort zur zehnten Auflage", Philosophie des Unbewussten, First part, Leipzig: Verlag von Wilhelm Friedrich, VII.

${ }^{49}$ On this line, we find for instance Grossmann's critique of the Hegelian dialectic interpreted as an antidemocratic process as deformation of Hegel's own views found in the Rechtsphilosophie, by a "folkisch-rassistischer Ideologie" dressed in metaphysical cloths. See: GROSSMANN, Andreas (2010): „Recht verkehrt. Hegels Rechtsphilosophie im Neuhegelianismus“, in: Recht ohne Gerechtigkeit? Hegel und die Grundlage des Rechtsstaates, Wischke, Mirko/ Przylebski, Andrzej (Hrsg.), Würzburg: Königshausen und Neumann, 191, 206, 208.

${ }^{50}$ This is true for Stirner, see also Hartmann (1898): "Stirners Verherrlichung des Egoismus", Ethische Studien, III, 80.

${ }^{51}$ Cf. STULPE, Alexander (2010): Gesichter des Einzigen. Max Stirner und die Anatomie moderner Individualität, Beiträge zur Politischen Wissenschaft Band 158, Berlin: Duncker \& Humblot.
} 
self-preservation. Von Hartmann sees the weight of suffering and interprets in his own way the point where Schopenhauer arrives, at the end of the fourth book of his great work: the negation of the will of life is the nothingness. He tries to find a meaningful philosophical project, grand enough to reshape the mesh of attitudes the affirmation of the will involves, in order to achieve a freedom of the ethics of injustice, because injustice consists in the negation of a third person's will. An ethical principle of redemption should be explored, thinks von Hartmann in the domain of the normativity of criminal legislation and justice, because false dependences of the part to the whole have to be overcome. Nietzsche was well aware of the universality of the ethical archetype of redemption when he writes: "the redeeming human being of great love and contempt...in this bell-stroke of noon and of the great decision, who makes the will free again, who gives back to the earth its goal and to humanity its hope $^{52 \%}$.

\section{Transfer of retribution to an entire political community}

The dangers of an excessive measure of personal retribution, that of a growth of animosity and hatred lead to a transfer of retribution to an institution that offers guarantees of fair omissions, and effective enforcement of penal measures. According to Hartmann, this institution is naturally the highest authority of the two participating communities, and grows with the development of culture ${ }^{53}$. This transfer can be interpreted in two ways. First, a community declares certain torts, which are already identified as public torts pre-legally. Instead of constituting interdictions, because reasons to abstain from killing, robbing or sexually abusing exist, the transfer of retribution to an institution that offers guarantees implies only drawing attention that these torts concern the entire political community, in contrast to fair omissions of retribution. This manner of presenting certain torts as clearly public, because criminal torts would be relational by the fact that we can specify the institution to which we are responsible, recalls a central argument of Duff's legal moralism. A second proposition on retribution should be presented which has a possible genetic relationship but not logical with the first. Since transfer of retribution should be more successful, according to Hartmann, through modifications of customs and an "expansion of basic communities of family and clan to the State ${ }^{54 \text { ", }}$ not through a contract, a practical additional condition has to be fulfilled. In order for the proposed transfer of retribution to function, citizens must agree on the fact that a procedure formed around community identity permits the structuring of the idea of a political society for all citizens. If that is the

\footnotetext{
${ }^{52}$ NIETZSCHE, F. (1887/1969): On the Genealogy of Morals, II, 24, transl. Kaufmann and Hollingdale. New York: Vintage Books.

${ }^{53}$ HARTMANN, Eduard von, PSB, "Das Moralprinzip des Gegengefühls", 201.

54 “Das Moralprinzip des Gegengefühls", 202.
} 
case, an agreement on the contents of the interdictions of that authority goes beyond the conditions sufficient for transfer ${ }^{55}$. Hartmann, who puts into perspective the significance of retribution, through his idea of transfer, seems to argue in favour of the idea that agreement involves less the value of an interdiction, considered as deserved, than a procedure based on an expansion of the community, in opposition to hedonistic calculations or to rational contractual agreement. In this case, it could still be asked whether persons, who cause certain torts deserve to be punished, and not be deprived or tested, and whether the State should be the recipient of a transfer of communities' retribution, in contrast to other organizations, which could also produce an appropriate degree of sanction. Hartmann's reply to these two possible questions departs from legal morality, in the sense that he stresses the political dimension of criminal justice on those two levels. The transfer from a group of communities, assimilable to networks under construction in civil society, towards a national community passes logically through the hands of the State, which should have a precise substantial interest ${ }^{56}$. But we do not find in Hartmann's writings that the State's interest in producing criminal justice is in preventing harm to others. There is also no reference to a right not to be punished, as a constitutional right, defined beyond a substantial interest of the State under penal rules ${ }^{57}$. Hartmann refers to the classic consequential arguments of a principle of general and specific prevention, without developing notions of interest and harm that he could have introduced into his analyse of Mill's social eudemonism, which he accepts rather favourably. Presented as a lesser evil, punishment can be seen as justified in situations in which the survival of society so requires. This type of reasoning will be associated with the ideas of a historic movement of realisation of State organism, but remains distinct of the normative task of explaining the problem of tyrannical paternalism, or just reflecting on unjustifiable costs of citizenship.

In contrast to a community based procedural approach of retribution, and to the development of a criterion of public utility, as reflexions on set back of interests associated with the prevention of harm to others, more than the first half of Hartmann's chapter on the moral principle of counter-sentiment constitutes bona fide a justification for a moral principle of retribution, with the mention of a possible basis in criminal law, as also found in Kant's and Hegel's writings ${ }^{58}$. As shown by Scheler, the difference with Hegel is that the requirement for retribution appears negatively in von Hartmann, as the ineffectiveness of an ethical power to pardon and express gratitude. What does it mean not being a

\footnotetext{
${ }_{55}$ An institutional proceduralism not based in a community but in a situation of ideal conformity seems less plausible, because it shows even less concern for substantial norms (prevention of a murder, theft, etc.). See also: DUFF, Answering for Crime, 87.

${ }_{56}$ Expressing hesitations to assign to the State production of penal sanctions seems rather reasonable, See HUSAK, Douglas (2008): Overcriminalization: The limits of the criminal law, New York: Oxford University Press, 204.

${ }^{57}$ The absence of external restrictions, for example through constitutional norms, approaches the idea of law as expressed by Hartmann of legal morality.

${ }^{58}$ Ibid. 202.
} 
positive ethical demand of retribution ${ }^{59}$ ? As only plausible answer, Hartmann's reflections on retribution stray from a legal morality that defends the idea that there should be a relational allocation of responsibility among participants in a civil society, such that this situation were superior when those responsible for torts are punished, in comparison to that where punishment is omitted.

Male fide, retribution is linked to a theory of emotions that brings out the egoistical character of a purpose that can become moral, but whose evolution towards a pseudo-moral set of norms is also possible. The second half of the section on retribution is critical ${ }^{60}$. On the one hand, various problems linked to the mode of transfer of a moral obligation are presented by Hartmann. Given that we easily convince ourselves of having an ethical understanding of retribution, when it concerns groups of persons or broad communities, retributive emotion leads to a collective "justice of lynching", not to an appropriate weighing of principles of justice. On the other hand, the comparison between retribution and development of hatred on a bilateral level, introduces the possibility of extreme perturbations of emotions caused by provocations. Clearly in favour of a substantial approach to tort and penal retribution based on merit, Hartmann mentions that prophylactic measures of preventive justice against crimes, not yet committed, are arising from an instinct of retribution of an unconscious reason. This set of norms includes apparently strictly legal torts, because there is a recursive effect of legality on the actions, "an influence that is stronger than all religions and moral systems taken together ${ }^{61}$ ". Hartmann maintains that it is a false approach to admit, first, that there is a content of retribution, without realising that an unconscious instinct exists, in any source of retribution. This simplified functional retribution will often deny any historical developments by focussing on its juridical penal dimension, and the adoption of short-term mechanisms that have a reduced effect over time. Second, there is a production of effects, not only reduced over time, but also insufficient, when penal end, in the name of perfection and dissuasion, pose a threat, without having to give an ethical justification that is appropriate to the instinct of retribution, by the fact that the latter are ends separate from ethical retribution.

Hartmann conclude his analysis of criminalization and self-control, described as a ruse of the conscious will by showing the aim of gratitude, as opposed to punitive retribution. From the point of view of material ethics, we can already perceive an asymmetry between retribution, linked to gratitude and that caused by suffering, because we can say that a harmful action suggest a remedy, in order to rebalance the depression of the egoistical feeling caused towards the injured party, while that is not so

\footnotetext{
${ }^{59}$ Scheler, "Das Verhältnis des Zusammenhangs von Glück und sittlichem Werte zur Idee der Sanktion und Vergeltung", 368.

${ }^{60}$ See HARTMANN, Eduard von, "Das Moralprinzip des Gegengefühls”, 208 and 211. Hartmann mentions Dühring's principe of vengeance refusing to grant a coherence to it. See also: DÜHRING, Eugen (1865): "Die transzendente Befriedigung der Rache", Der Wert des Lebens, Breslau: 219-225.

${ }^{61}$ See "Das Moralprinzip des Gegengefühls", 205.
} 
easily acknowledged for a good action. Although retribution is the closest form of remedy, according to Hartmann, towards which we are instinctively inclined, it is not the only possible remedy in order to re-establish the level of ethical states of comparable weight. Magnanimity and pardon are perceived as noble attitudes, while vengeance is considered to be natural. Retribution redresses a situation to a lower level, because there was in the meantime a humbling and an imposed restriction. In comparison, a pardon is a positive act that compensates the negative weight of a crime, towards a balance of ethical states of comparable weight, in order to reach the status quo ante. While retribution evokes only rarely the knowledge that penitence is merited, and that a crime can be expiated graciously. It is far closer to hatred, against the person offering penitence (whether it is a person, a company or the State). On the contrary, a pardon and the magnanimity of the person that has been harmed can provoke an ethical shame in the person causing harm, leading to self-awareness and improvement ${ }^{62}$. Neither retribution nor pardon will have any effect against a brutal or obstinate person, who will see retribution as acquittal of wickedness and hatred, and magnanimity as a weakness.

\section{Bibliography}

DARNOI, Dennis N. Kenedy: The unconscious and Eduard von Hartmann. A historico-critical monograph. The Hague: Martinus Nijhoff, 1967.

DUFF, R. Antony. Answering for Crime. Portland-Oregon: Hart Publishing, 2007.

HAAZ, Ignace. La solidarité chez Hegel, von Hartmann, Tocqueville et Mill. Paris: Éditions L'Harmattan, 2012 (Coll. Commentaires philosophiques).

. „L'invention des conventions de justice chez Hume et sa skepsis envers la rétribution“, In: L'invention philosophique humienne, Philippe Saltel (dir.), Grenoble: Université Pierre Mendès France, 2009, pp. 235-72.

HARTMANN, Eduard von. Philosophie des Unbewussten. Tenth edition in three parts. Leipzig: Verlag von Wilhelm Friedrich, 1869/1889.

Philosophy of the Unconscious. Transl. by W. C. Coupland. London: Kegan Paul, Trench, Trübner, \& Co. Ltd, 1893.

. Phänomenologie des sittlichen Bewusstseins: Prolegomena zu jeder künftigen Ethik. Berlin: C. Dunker Verlag, 1879.

. „Die Axiologie und ihre Gliederung“, Zur Geschichte und Begründung des Pessimismus. 2a Auflage, A.I. Leipzig: Hermann Haacke Verl., 1890, pp. 1-17.

${ }^{62}$ Ibid. 209. 
. "Stirners Verherrlichung des Egoismus". In: Ethische Studien, Dritte Aufsatz. Leipzig: Hermann Haacke, 1898, pp. 70-90.

. Nietzsches „Neue Moral“. In: Ethische Studien, II, 1898, pp. 34-69.

. "Ethik und Eudämonismus". In: Ethische Studien, Siebente Aufsatz, Leipzig: Hermann Haacke, 1898, pp. 160-227.

. "Sozialdemokratie und Anarchismus als Abspaltungen aus dem Liberalismus", Zur Zeitgeschichte: neue Tagesfragen. Leipzig: Hermann Haacke, 1896/1900.

HUSAK, Douglas. Overcriminalization: The limits of the criminal law. New York: Oxford University Press, 2008.

JENSEN, Anthony. „Das Unbewusste durch die Historie enthüllt: der bejahende Einfluss Hartmanns auf Nietzsche“. In: Nietzsches Philosophie des Unbewussten. Ed. by Georg, Jutta/Zittel, Claus. Berlin: Walter de Gruyter Verl., 2012, pp. 157-162.

JOHNSON, Jane. An Idealist Justification of Punishment. Saarbrücken: VDM Verlag Dr. Müller, 2008.

KANT, Immanuel. The Metaphysics of Morals, 1797/1994. In: Immanuel Kant, Practical Philosophy. Ed. Mary Gregor. Cambridge: Cambridge University Press, 1996.

KANT, Immanuel. Werke in Sechs Bänden. Hrsg. von Wilhelm Weischedel, Wissen-schaftliche Buchgesellschaft, 6. Aufl. Wiesbaden: Insel Verlag, 2005.

KOSSLER, Matthias; MÜLLER-SEYFARTH, Winfried H; REGEHLY, Thomas. Politik und Gesellschaft im Umkreis Arthur Schopenhauer. Würzburg: K \& N, 2008.

MAINLÄNDER, Philipp. „Kritik der Hartmann'schen Philosophie des Unbewußten“. In: Philosophie der Erlösung, 2. Band, 1886.

MERLE, Jean-Christoph. German Idealism and the Concept of Punishment. Cambridge: UP, 2009.

MÜLLER-SEYFARTH, Winfried H. Die modernen Pessimisten als décadents - Von Nietzsche zu Horstmann. Texte zur Rezeptionsgeschichte von Philipp Mainländers "Philosophie der Erlösung", Würzburg: Verl. Königshausen \& Neumann GmbH, 1993.

NIETZSCHE, Friedrich. Sämtliche Werke. Kritische Studienausgabe. Hrsg. von G. Colli und M. Montinari. Berlin: W. de Gruyter, 1980/1999.

REGINSTER, Bernard. The Affirmation of Life. Harvard: Harvard University Press, 2006.

SCHOPENHAUER, Arthur. Die Welt als Wille und Vorstellung. Zürich: Diogenes Verlag, 1873/1977. $1841 / 1995$.

On the Basis of Morality. E. F. J. Payne, trans. New York: Oxford University Press,

TAKEDA, Sumio. “Vitalism and Kegon Buddhism”. In: New Nietzsche Studies, Vol. 8, No 3-4, 2012. 
WOLF, Jean-Claude. Eduard von Hartmann. Ein Philosoph der Gründerzeit. Würzburg: Königshausen \& Neumann, 2006.

. Das Böse. Berlin/Boston: Walter de Gruyter GmbH, 2011.

STOECKER, R. (Ed.). Menschenwürde - Annäherung an einen Begriff. Vienna, 2003.

BAUMANN, Johann Julius. "Das Recht überwiegend von Seiten der Gemeinschaft betrachtet". In: Abriss der Rechtsphilosophie. Leipzig: Verlag von S. Hirzel, 1879.

SPINOZA, Baruch. Ethics. In: The Collected Writings of Spinoza, E. Curley transl. Princeton: Princeton University Press, vol. 1, 1677/1985. 